\title{
SEQUENCING BATCH REACTOR WITH SUBMERGED HOLLOW FIBRE MEMBRANES FOR THE BIOMASS SEPARATION
}

\author{
Jörg Krampe and Karlheinz Krauth \\ Institute for Sanitary Engineering, Water Quality and Solid Waste Management, \\ University of Stuttgart, Bandtäle 2, D-70569 Stuttgart, Germany
}

\begin{abstract}
A method to reduce the cycle time of the SBR-process by utilising submerged membranes is described. The time necessary for the sedimentation of the activated sludge and the extraction of the clear-water phase takes up a major part of the entire cycle period within the SBR-process. By using membranes it is possible to start the clear-water extraction already during the reaction time. The time needed for the sedimentation of the activated sludge can be dispensed with altogether. The paper presents the initial results of a semi-technical test plant, with particular emphasis on the fact that the running of the SBR-plant did not lead to any problems with fouling or scaling. In cases of high solids contents, the oxygen input was below par; this, however, did not have any unfavourable impact on the nitrification.
\end{abstract}

\section{KEYWORDS}

Membrane filtration, SBR, hollow fibre modules, nitrogen elimination, activated sludge process

\section{INTRODUCTION}

In recent times, there have been a large number of examinations to utilize membranes for the separation of the biomass. This method has been realised on an industrial scale in both municipal and industrial wastewater treatment. One advantage is the possibility to achieve very high solids contents and thus to reduce the necessary tank volume. With an accordingly lower sludge load, it is also possible to minimise the production of surplus sludge; this, however, increases the energy demand [Günder, 1999].

The utilisation of ultra- or microfiltration membranes makes a germ-free effluent, which is advantageous in regard to the Council Directive 76/160/EEC concerning the quality of bathing water. Moreover, membranefiltrated wastewater is suitable for direct infiltration or for re-use. Areas of utilisation are, for instance, small wastewater treatment plants in rural areas or industrial factories with high water consumption.

In this report, the utilisation of submerged membranes in a test plant which is run as a SBR-plant is presented.

\section{BASIC INFORMATION ON USING MEMBRANE FILTRATION IN SBR-PLANTS}

CIWA Publishing 2001. The definitive peer-reviewed and edited version of this article is published in Water Science \& Technology, Volume 43, Issue 3, 195-199, 2001, doi:10.2166/wst.2001.0137 and is available at www.iwapublishing.com. This is the accepted version. 
The combination of membrane filtration with the SBR-operation method makes procedural advantages for both methods. Mostly, the flow through the submerged membranes is effected by the aeration installed directly below them in order to reduce the emergence of a surface layer. Such a layer would prevent the regulation of the air supply, which in turn would lead to increased oxygen concentrations in the reactor. In a conventional membrane bioreactor with pre-denitrification, this phenomenon might lead to a continuous oxygen input into the denitrification zone. This problem is prevented in SBR-plants, because the inflow during the filling phase guarantees a fast reduction of the oxygen concentration in the reactor.

The use of membranes allows to completely dispense with the sedimentation phase. As the reactor can continue to be aerated during the filtration phase - with submerged membranes the reactor even must be aerated -, all biological processes continue to run during this period. Thus, cycle time and reaction time become equal. Furthermore, it is possible to work with small exchange ratios, as the sedimentation performance of the activated sludge does not have any impact any more. This leads to very high nitrogen elimination rates.

The germ-free effluent makes the re-use of the purified wastewater much easier, which is a major factor, especially in industrial applications, where the SBR-method is the favoured application anyway. Depending on the design and constellation of the membrane, one differentiates between modular or conditionally modular systems. The membranes can be integrated either as submerged membranes within

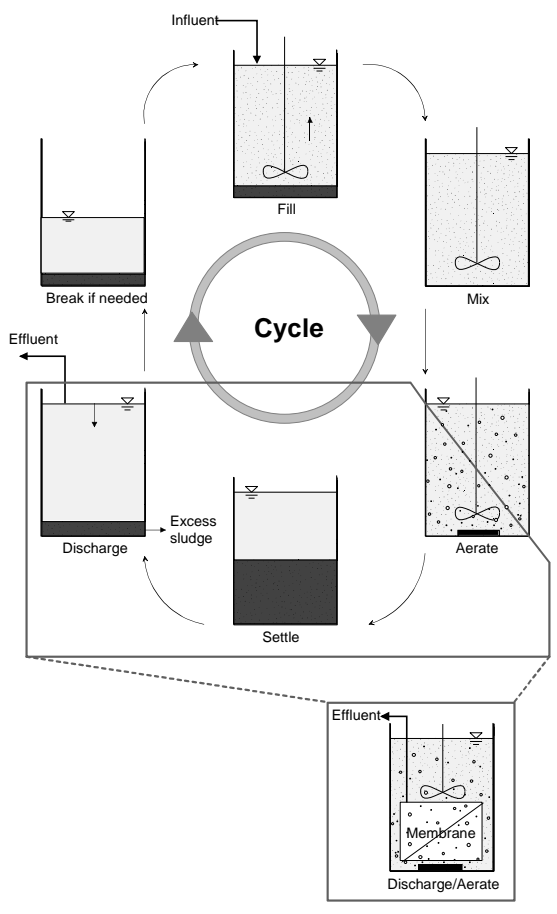

Figure 1. Modified cycle by using membranes the reactor, or externally, for instance as tubular modules. With several reactors, the external application did make for a better exploitation of the membrane surface area. The variation with submerged membranes, however, is a purely modular system, which can easily be gradually enlarged and offered according to the modular principle.

\section{DESCRIPTION OF THE PILOT PLANT}

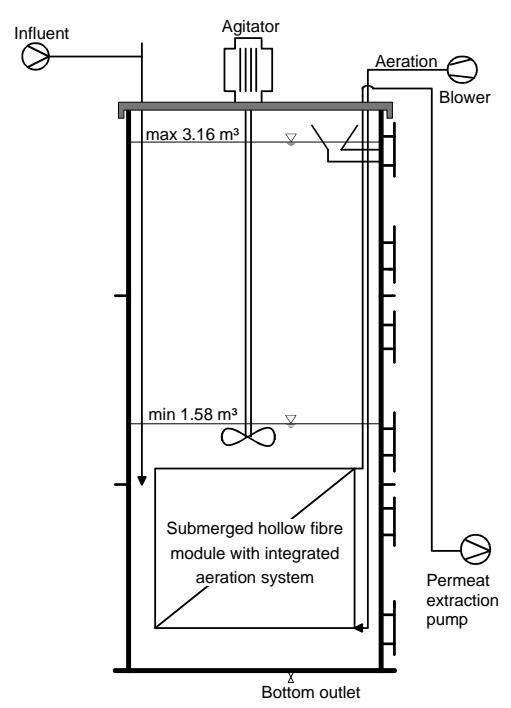

Figure 2. Pilot plant

The pilot plant consists of a reactor with a maximum filling volume of $3.16 \mathrm{~m}^{3}$ and a minimum volume of $1.58 \mathrm{~m}^{3}$, which allows for a maximum exchange ratio of 0.5 . Submerged hollow fibre membranes with a membrane surface area of $64 \mathrm{~m}^{2}$ are integrated into the reactor. The plant is charged with pre-treated municipal wastewater from the Teaching and Research Sewage Treatment Plant Büsnau. Table 1 presents a survey of the average wastewater composition during the test period. Figure 2 shows the plan of the test plant.

Table 1. Average influent concentrations

\begin{tabular}{ccccc}
\hline $\mathrm{COD}[\mathrm{mg} / \mathrm{l}]$ & $\mathrm{BOD}_{5}[\mathrm{mg} / \mathrm{l}]$ & $\mathrm{TKN}[\mathrm{mg} / \mathrm{l}]$ & $\mathrm{P}_{\text {total }}[\mathrm{mg} / \mathrm{l}]$ & $\mathrm{SS}[\mathrm{mg} / \mathrm{l}]$ \\
\hline 382.2 & 229.3 & 58.4 & 7.1 & 147.0 \\
\hline
\end{tabular}

The control of the plant is done via PC. It is possible to control the cycle times according to a fixed schedule or in accordance to the measured values; the exchange ratios in the single test runs have hither to been kept constant.

CIWA Publishing 2001. The definitive peer-reviewed and edited version of this article is published in Water Science \& Technology, Volume 43, Issue 3, 195-199, 2001, doi:10.2166/wst.2001.0137 and is available at www.iwapublishing.com. This is the accepted version. 


\section{INITIAL RESULTS}

In the first test period, the plant was run with varying exchange ratios within a fixed schedule which was geared according to these variations. The exchange ratio $\mathrm{f}_{\mathrm{A}}$ is defined as the ratio between the entire volume and the volume exchanged per cycle. Particularly the exchange ratios $f_{A}=0.1,0.2$ and 0.3 are examined. A general rule is of course that a low exchange ratio allows for good effluent values. The conversion rates, however, are then accordingly low. At a high exchange ratio, high conversion rates are achieved, but then the effluent values are worse.

\section{Membrane flow}

Throughout the entire examination period, the permeate extraction was interrupted every 8 minutes for 2 minutes in order to achieve a reduction of the emerging surface layer. The membrane flow was for all cases fixed and gradually increased during the initiation phase to $10 \mathrm{l} / \mathrm{m}^{2} \mathrm{~h}$. During the constant operation, the trans-membrane pressure increased from 10 to $25 \mathrm{kPa}$. The membrane manufacturers had given a warranty for a maximum trans-membrane pressure of $25 \mathrm{kPa}$. Whenever this pressure was reached, the module was cleaned. For cleaning, the entire module was lifted out of the reactor into a cleaning tank in one go together with the topped stirring implement, the aeration

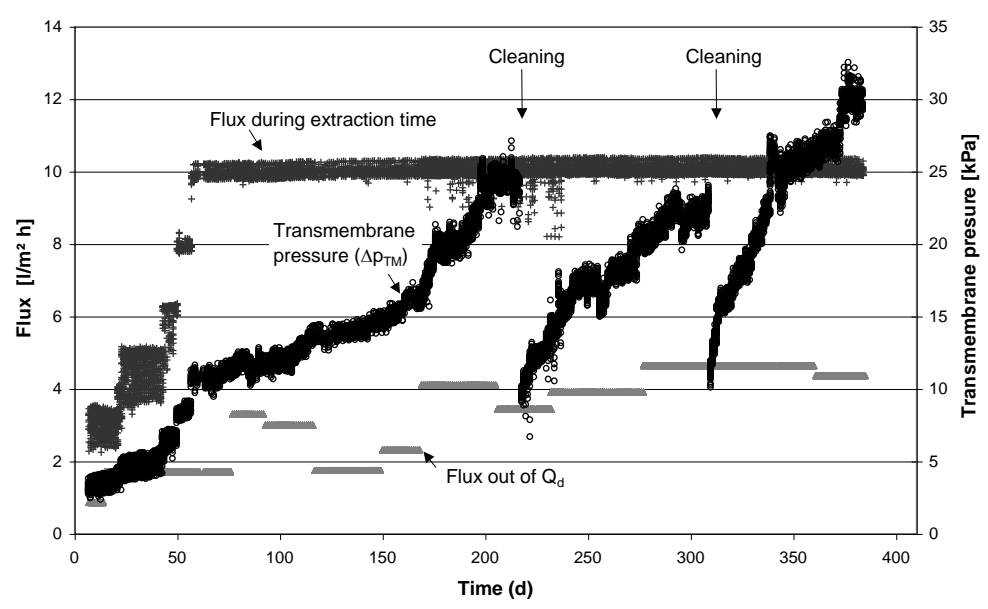

Figure 3. Flux and transmembrane pressure of the membranes

pipes, and the permeate extraction pipelines. The cleaning itself was done over night in a natrium-hypochloride solution with the aeration switched on. After that, the module was set back into the bioreactor, and the plant was started again. Figure 3 clearly shows the successful impact of the cleaning: after cleaning, the trans-membrane pressure was - with the same solids contents - back in the range of $20 \mathrm{kPa}$. From now on, the target must be to reduce the cleaning time, in order to increase the availability of the plant.

\section{Biological performance}

Table 2 shows the crucial parameters for the single test periods. The given cycle times are those which had been fixed respectively for the entire test runs.

Table 2. Crucial parameter for the first test period

\begin{tabular}{|c|c|c|c|}
\hline Exchange ratio: & 0.1 & 0.2 & 0.3 \\
\hline Throughput $\left[\mathrm{m}^{3} / \mathrm{d}\right]$ & 3.60 & 5.07 & 6.49 \\
\hline Cycle time [minutes] & 83 & 120 & 161 \\
\hline Sludge loading [kg BOD 5 / kg MLSS d] & 0.029 & 0.034 & 0.062 \\
\hline Excess sludge production $[\mathrm{kg} / \mathrm{d}]$ & 0.44 & 0.57 & 1.03 \\
\hline $\mathrm{COD}_{\text {eff }}[\mathrm{mg} / \mathrm{l}]$ & 14.7 & 13.4 & 17.4 \\
\hline $\mathrm{NH}_{4}{ }^{+}-\mathrm{N}_{\mathrm{eff}}[\mathrm{mg} / \mathrm{l}]$ & 0.4 & 1.5 & 1.7 \\
\hline $\mathrm{NO}_{\mathrm{x}}{ }^{-}-\mathrm{N}_{\mathrm{eff}}[\mathrm{mg} / \mathrm{l}]$ & 7.1 & 8.7 & 17.9 \\
\hline COD-elimination [\%] & 94.5 & 94.2 & 93.6 \\
\hline Nitrogen-elimination [\%] & 86.6 & 79.5 & 67.1 \\
\hline
\end{tabular}

CIWA Publishing 2001. The definitive peer-reviewed and edited version of this article is published in Water Science \& Technology, Volume 43, Issue 3, 195-199, 2001, doi:10.2166/wst.2001.0137 and is available at www.iwapublishing.com. This is the accepted version. 
A typical curve of a measured cycle is shown in Figure 4. Already during the filling phase, the oxygen concentration in the reactor drops rather fast. Parallel to that, the nitrate nitrogen remaining from the previous cycle is denitrified. During this time, there is a slow increase of the $\mathrm{NH}_{4}{ }^{+}-\mathrm{N}$ concentration. This slow increase is caused on the one hand by mixing processes within the measuring circulation, on the other hand by a slowed-down hydrolysis in anoxic conditions. Thus, the measured $\mathrm{NO}_{\mathrm{x}}{ }^{-}-\mathrm{N}$ concentration is always higher than the previously measured $\mathrm{NH}_{4}{ }^{+}-\mathrm{N}$ concentration, because the end of the hydrolysis inhibition immediately effects the beginning of the nitrification.

Furthermore, the start of the aeration leads only to a slow increase of the oxygen concentration in the reactor. This can be explained to some degree by the fact that the initial oxygen demand is very high. A larger impact, however, is created by the low oxygen transfer at high concentrations of mixed-liquor suspended solids (MLSS). During the tests, the MLSS in the minimal filling state was constantly kept at $15 \mathrm{~g} / \mathrm{l}$. With an exchange ratio of $\mathrm{f}_{\mathrm{A}}=0.2$, the resulting solids contents during the reaction phase is $12 \mathrm{~g} / \mathrm{l}$. For this MLSS contents, GÜNDER (1999) gives an $\alpha$-value of 0.37. Despite the low oxygen contents, there were no negative impacts on the nitrification.

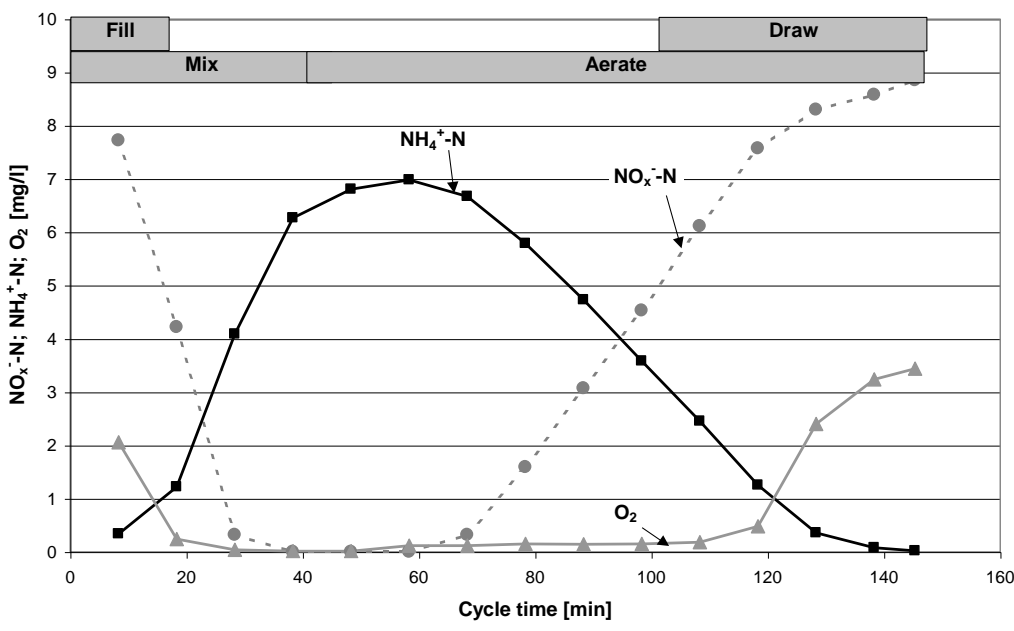

Figure 4. Typical concentration profile for an exchange ratio of 0.2

Once a month, samples of the germs in the effluent were taken and examined; the results are listed in Table 3. The samples were tested for those bacteria relevant for the Council Directive 76/160/EEC concerning the quality of bathing water - fecal streptococci, fecal coliforms, and total coliforms. The high values of the sample from day 177 were due to a contamination of the effluent pipes, not to any membrane defects.

Table 3. Results of the microbiological analytic during the first test period

\begin{tabular}{cccc}
\hline $\begin{array}{c}\text { Experimental } \\
\text { day }\end{array}$ & $\begin{array}{c}\text { Fecal streptococci } \\
{[/ 100 \mathrm{ml}]}\end{array}$ & $\begin{array}{c}\text { Fecal coliforms } \\
{[\mathrm{MPN} / 100 \mathrm{ml}]}\end{array}$ & $\begin{array}{c}\text { Total coliforms } \\
{[\mathrm{MPN} / 100 \mathrm{ml}]}\end{array}$ \\
\hline 44 & neg. & 0.4 & 0.9 \\
78 & neg. & 1 & 4 \\
127 & neg. & neg. & 1 \\
177 & 6 & 15 & 110 \\
198 & 1 & 0.4 & 2 \\
\hline
\end{tabular}

\section{CONCLUSION}

It could be shown that the utilisation of submerged membranes in SBR-plants is technically feasible. Apart from the fact that cycle times and reaction times become equal, this method combination allows very low exchange ratios, as the sedimentation performance of the activated sludge is of no importance. Further experiments should focus on an optimal utilisation of the installed membrane surface. This is for example possible by sharing one membrane unit between several reactors.

CIWA Publishing 2001. The definitive peer-reviewed and edited version of this article is published in Water Science \& Technology, Volume 43, Issue 3, 195-199, 2001, doi:10.2166/wst.2001.0137 and is available at www.iwapublishing.com. This is the accepted version. 


\section{ACKNOWLEDGEMENTS}

The authors would like to thank the Willy-Hager-Stiftung Stuttgart, who financially supported this project.

\section{REFERENCES}

Günder, B. (1999). Das Membranbelebungsverfahren in der kommunalen Abwasserbehandlung, Stuttgarter Berichte zur Siedlungswasserwirtschaft, Bd. 153, Oldenbourg-Verlag, München

Günder, B., Krauth, Kh. (1998). Replacement of secondary clarification by membrane separation - results with plate and hollow fibre modules. Wat. Sci. Tech., 38(4-5), pp. 383-393.

CIWA Publishing 2001. The definitive peer-reviewed and edited version of this article is published in Water Science \& Technology, Volume 43, Issue 3, 195-199, 2001, doi:10.2166/wst.2001.0137 and is available at www.iwapublishing.com. This is the accepted version. 